\title{
Hydraulic cell compression for performance preserving upscaling of PEM electrolyzers
}

\author{
Florian J. Wirkert*, Jeffrey Roth, Ulrich W. Rost, Michael Brodmann \\ Westfälische Hochschule Gelsenkirchen Bocholt Recklinghausen University of Applied Sciences \\ Neidenburger Str. 43, 45897 Gelsenkirchen, Germany
}

\begin{abstract}
The technology of polymer electrolyte membrane (PEM) electrolysis provides an efficient way to produce hydrogen. In combination with renewable energy sources, it promises to be one of the key factors towards a carbon-free energy infrastructure in the future. Today, PEM electrolyzers with a power consumption higher than $1 \mathrm{MW}$ and a gas output pressure of 30 bar (or even higher) are already commercially available. Nevertheless, fundamental research and development for an improved efficiency is far from being finally accomplished, and mostly takes place on a laboratory scale. Upscaling the laboratory prototypes to an industrial size usually cannot be achieved without facing further problems and/or losing efficiency. With our novel system design based on hydraulic cell compression, a lot of the commonly occurring problems like inhomogeneous temperature and current distribution can be avoided. In this study we present first results of an upscaling by a factor of 30 in active cell area.
\end{abstract}

Keywords: Hydraulic cell compression, PEM electrolysis, upscaling laboratory models.

\section{Introduction}

As the climate changes rapidly and thus, threatens the intactness of the environment, immense effort is being invested worldwide to stop the greenhouse effect and stabilize the climate. Germany has decided that $80 \%$ of its electrical energy should be produced by renewable energy sources by 2050 [1]. To reach this ambitious objective, large capacities for photovoltaics and wind turbines need to be installed [2]. Here, one of the main problems to overcome is the difference between consumer demand and energy supply, which is dependent on the environmental conditions (daytime, season, local conditions). A second problem is the delocalized energy production. Hence, solutions need to be found concerning grid integration, smart grids and intelligent storage possibilities. Therefore, an expanded use of hydrogen as energy carrier is one of the tasks that need to be realized, especially in combination with wind turbines [2].

In order to efficiently use hydrogen as a storage medium for the excess energy produced by renewable energy sources, appropriate technologies are necessary. Here, dynamic operation is an issue as well as high pressure gas output for external storage without causing further (cost-intensive) efforts. Polymer electrolyte membrane electrolysis (PEM-electrolysis) is able to meet these goals. But, up to now, hydrogen production using PEM-electrolyzers is not yet economically, as hydrogen production by steam reforming is much more cost effective. In order to build and operate PEM-electrolysis systems on the same level as steam reformers (concerning costs per kg hydrogen output), large scale (> MW) and longterm stable (several years) systems are required [3], [4]. On the other hand, the conversion of the stored chemical energy back to electrical energy seems to be rather settled, as fuel cell technology is already commonly used [5]. As on the field of PEM-electrolysis, huge progress has been achieved in recent years [6] and largescale systems have been built already [4]. Regardless, further fundamental research and development on a laboratory scale is a necessity.

\footnotetext{
* Manuscript received January 23, 2017; revised May 5, 2017.

Corresponding author. Tel.: +49-209-9596-806; E-mail address: florian.wirkert@w-hs.de.

doi: $10.12720 /$ sgce.6.3.171-176
} 
One of the major tasks that need to be handled when it comes to the development of durable PEMelectrolyzers is the degradation of the membrane over time. Besides contamination with foreign elements, which is mostly driven by impurities in the feed water, membrane thinning is one of the key mechanisms that lead to efficiency losses and cell failures [7]. This effect is strongly dependent on the given temperature conditions and the current density [8]. As the thinnest spot is deterministic for the lifetime of a membrane, the occurrence of so-called hot spots needs to be avoided. Otherwise, even the destruction of cells up to entire systems may occur [9]. For a homogeneous temperature and current distribution, at first, a homogeneous compression over the complete active area needs to be guaranteed [10]. This is especially important when it comes to larger active areas, which, on the other hand, are crucial for industrial scale PEM-electrolyzer systems.

With our novel concept of hydraulic cell compression we are able to avoid at least the mentioned problem, as we achieve a homogeneous pressure distribution independent of the size of the active area. In addition to that, further benefits arise with the usage of a hydraulic medium for cell compression. For example, the compression can be kept constant even with a dynamic alteration of the gas output pressure [11], [12] and waste heat can be recovered to further increase the systems efficiency.

\section{Experimental}

\subsection{Cell design}

The electrolyzer cells were designed with a focus on the possibility of a cost-effective construction and the use of parts and materials, which are commonly available. Also, the central point of this study was to show the feasibility of a performance preserving upscale instead of developing a high performance electrolyzer cell. For both reasons, a planar layout was chosen for the key parts inside the single cells.

To electrically contact the membrane electrode assembly (MEA) and to provide feed water and transport the produced gases, respectively, Titanium meshes are used as porous current distributors (PCD). The process media flows directly through the PCDs, input and output was done via plastic frames. Hence, no flow field was required and simple Copper sheets (coated for corrosion resistance) could be used for current conduction in and out of the cells. The schematic drawing in Fig. 1 (a) shows the structure of the cells interior. Detailed descriptions of the working principles are published in [11]-[14]. For a proper pressure transmission to the active area, flexible pads are installed in the frames at the respective areas (see Fig. 1 (b); not visible at the small cell).

The laboratory scale cell had an active area of $20 \mathrm{~cm}^{2}$, whereas the industrial scale cell's active area was $600 \mathrm{~cm}^{2}$, therefore, a factor of 30 larger than that of the laboratory scale cell (see Fig. 1 (b)). In order to validate the performance preserving upscaling, MEAs used were obtained from the same manufacturer and made within the same batch.

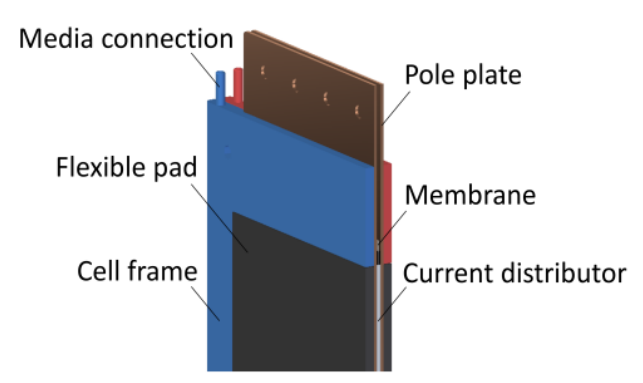

(a)

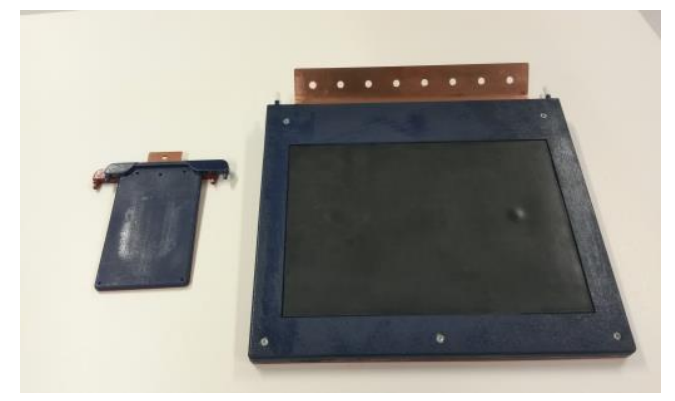

(b)

Fig. 1. Used electrolyzer cells: (a) Schematic drawing of the cross section of the industrial scale cell and (b) Photograph of the used cells. Left: Laboratory scale cell. Right: Industrial scale cell. 


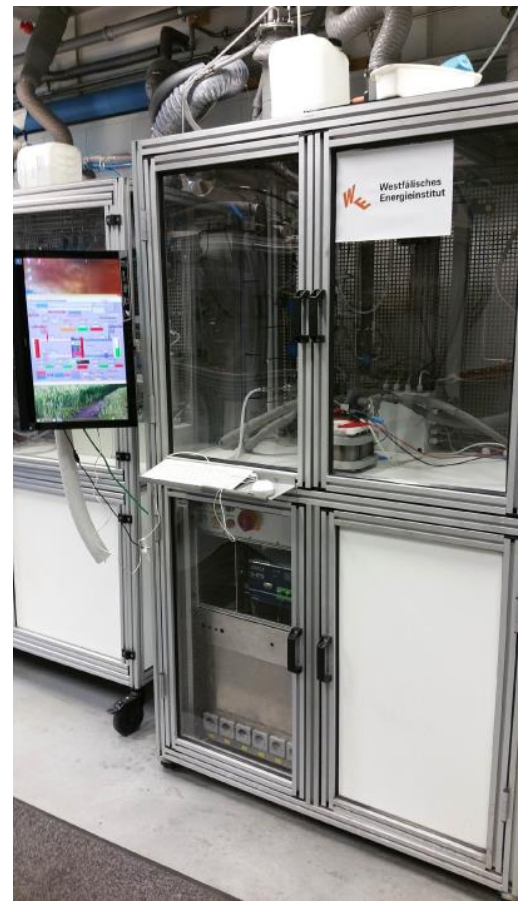

Fig. 2. Photograph of the used test bench. A stack to operate the laboratory scale cells is installed.

\subsection{Test environment}

The experiments were carried out at our facility using a custom built test bench. During each test run, only single cells were operated at one time. Media going to the cell (feed water) and media coming from the cell (water plus produced gases) were monitored via temperature and pressure sensors, cell voltage and current were measured constantly.

For the small, laboratory scale cells, the concept of hydraulic compression has already been validated. A stack for up to four cells, which can singly be exchanged, also, was already constructed [13], [14]. Fig. 2 shows a photograph of the used test bench.

For the larger, industrial scale cell, a proper compression device was built up. Here, at first, a tool to operate a single cell was set up instead of a whole stack, in order to investigate the upscaling effects. A special DC power supply (Sorensen DHP 10-1000) with high current output at low voltage was used to perform the test runs.

The pressure distribution over the cells active area was studied ex-situ before the respective cell tests via a pressure sensitive foil (Fujifilm Prescale Ultra Super Low (pressure range 0.2 to 0.6 MPa)).

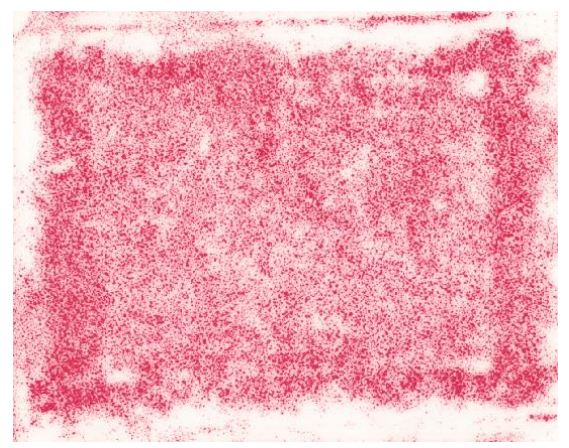

Fig. 3. Pressure distribution over the laboratory scale active cell area depicted via a pressure sensitive foil. 


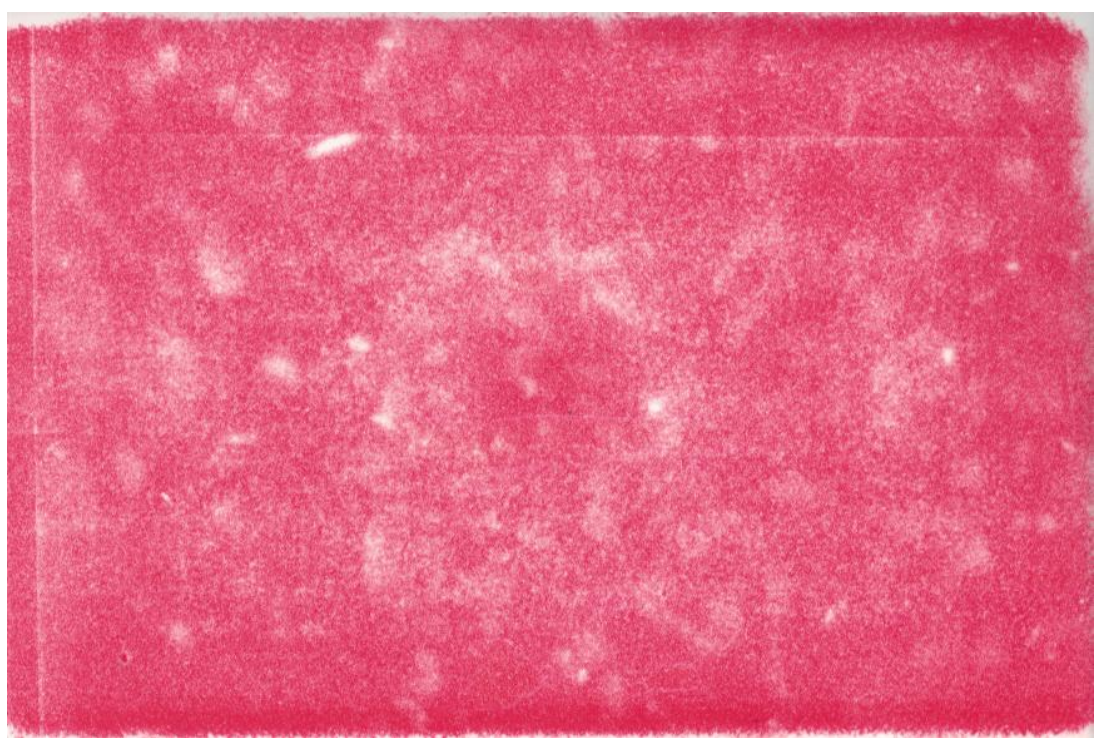

Fig. 4. Pressure distribution over the industrial scale active cell area depicted via a pressure sensitive foil.

\section{Results}

The results of the initially performed compression tests are shown in Figures 3 and 4 (not to scale). The intensity of the red color corresponds to the applied pressure at the respective area. In both cases, a homogeneous distribution of color, and thus, of applied pressure was obtained. The visible micro structure originates from the used PCDs' surfaces. The larger white areas visible in Fig. 4 are subject of ongoing investigations, as they can conceptionally only be caused by the PCD structure or 'dead spots' at the pressure sensitive foil.

After the pressure testing, the cells' performances were examined by recording polarization curves. Therefore, test runs were carried out by consecutively operating both cells with comparable environmental parameters, i.e. the same compression level ( 6 bar), the same cell temperature of $50{ }^{\circ} \mathrm{C}$, and a constant water flow at the anode side as well as at the cathode side. The obtained results are shown in Fig. 5.

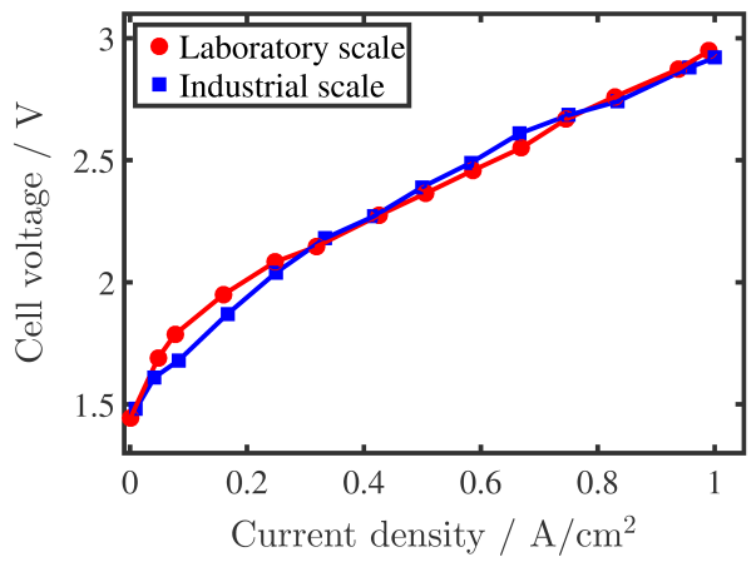

Fig. 5. Polarization curves recorded during the test run using the laboratory scale cell and the industrial scale cell, respectively.

As can be seen, the behavior is the same for the laboratory scale cell as for the industrial scale cell. 
With these results, one of the major benefits of hydraulic cell compression compared to conventional cell compression via thick plates and bolts, i.e. a performance preserving upscaling of the active area, has been proven experimentally.

\section{Conclusion and Outlook}

With the concept of hydraulic cell compression the assumption of a homogeneous pressure, and therefore, current as well as temperature distribution over the entire active cell area immediately suggests itself. An existing cell design was up-scaled by a factor of 30 , in order to investigate possible consequences. The performance of the system (normalized to the active cell area) is not affected as the results of this study show. A homogeneous pressure distribution throughout the entire active industrial scale cell area was proven via ex-situ testing using pressure sensitive foils. Also, the recorded polarization curve was similar to the one obtained using the laboratory scale prototype. Further testing will show the reliability of these first results. However, building industrial scale electrolyzers directly by simply upscaling the laboratory scale cell design without any further complications using hydraulic compression vastly decreases development costs and time.

Still, some issues need to be handled. Therefore, there will be two major topics dominating the future work. On one hand, the overall cell performance needs to be improved. Here, a minimization of the electrical contact resistance throughout the entire cell will be the initial step. On the other hand, long-term testing will be performed. This will give further evidence whether the formation of hot spots is permanently avoided. As part of this test, information on the behavior and stability of the system on a larger time-scale will also be obtained. In addition to these tasks, an industrial scale prototype stack will be constructed in order to investigate the system's performance during multi cell operation. Here, one focus will be on the temperature control via the hydraulic medium.

\section{Acknowledgement}

Presented results have been obtained within the scope of a research project, which is financially supported by the LeitmarktAgentur. NRW within the scope of the program Energie Umweltwirtschaft. NRW (funding number: EFRE-0800099). Furthermore, the authors gratefully acknowledge the supportive work of the industrial project partners, iGas engineering $\mathrm{GmbH}$, ProPuls $\mathrm{GmbH}$, and Obitronik GmbH, Germany.

\section{References}

[1] Gesetz zur Neuregelung des Rechtsrahmens für die Förderung der Stromerzeugung aus Erneuerbaren Energien. Bundesgesetzblatt, Teil 1, Nr. 42, 2011:1634-1678.

[2] Tangermann S. Mehr Windgas für mehr Klimaschutz. HZwei, 2016; 4:20-21.

[3] Millet P. Degeneration processes and failure mechanisms in PEM water electrolyzers. In: PEM Electrolysis for Hydrogen Production, Bessarabov D, Wang H, Li H, Zhao N, editors., Boca Raton: CRC Press; 2016:219-241.

[4] Danilovic N, Ayers K, Capuano C, Renner J, Wiles L, Pertoso M. Challanges in going from laboratory to megawatt scale PEM electrolysis. ECS Transactions, 2016; 75(14):395-402.

[5] Barbir F. PEM Fuel Cell Theory and Practice. 2nd ed. San Diego: Waltham; 2013.

[6] Carmo M, Fritz DL, Mergel J, Stolten D. A comprehensive review on PEM water electrolysis. Int. J. Hydrogen Energy, 2013; 38:4901-4934.

[7] Grigoriev SA, Dzhus KA, Bessarabov DG, Millet P. Failure of PEM water electrolysis cells: case study involving anode dissolution and membrane thinning. Int. J. Hydrogen Energy, 2014; 39:20440-20446.

[8] Chandesris M, Médeau V, Guillet N, Chelghoum S, Toby D, Fouda-Onana F. Membrane degradation in PEM water electrolyzer: numerical modeling and experimental evidence of the influence of temperature and current density. Int. J. Hydrogen Energy, 2015; 40:1353-1366.

[9] Millet P, Ranjbari A, de Guglielmo F, Grigoriev SA, Aupretre F. Cell failure mechanism in PEM water electrolyzers. Int. J. Hydrogen Energy, 2012; 37:17478-17487.

[10] Selamet OF, Ergoktas MS. Effects of bolt torque and contact resistance on the performance of the polymer electrolyte 
membrane electrolyzers. J. Power Sources, 2015; 281:103-113.

[11] Wirkert FJ, Roth J, Rost U, Brodmann M. A novel PEM electrolysis system with dynamic hydraulic compression for an optimized high-pressure operation. Presented at: 2016 NEIS conference, Hamburg, Germany.

[12] Brodmann M, Greda M, Mutascu C, Neumann J, Rost U, Roth J, Wildometz A. Method and system for operating an electrolyser. Int. Patent WO002014040746A1, 2014.

[13] Rost U, Roth J, Brodmann M. Modular polymer electrolyte membrane fuel cell and electrolyser stack design with hydraulic compression. Presented at: 2015 Energy Student Summit, Dortmund, Germany.

[14] Rost U, Roth J, Brodmann M. Ein neuartiges konzept für hochdruckelektrolyseursysteme in modularer bauweise zur produktion von wasserstoff aus überschussenergie erneuerbarer Quellen. In: Smart Energy 2015 Energiewende regional Trends, Treiber, Allianzen, Großmann U, Kunold I, Engels C, editors., Glückstadt: Werner Hülsbusch; 2015:67-73. 